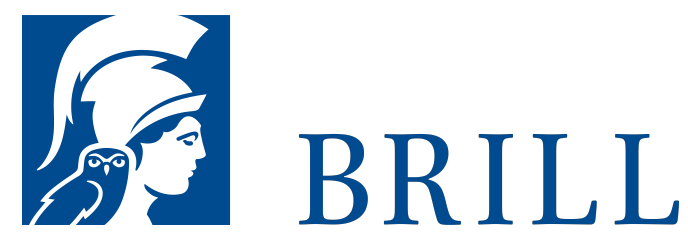

\title{
Discourses of Disease
}

Writing Illness, the Mind and the Body in Modern China

Editor: Howard Y. F. Choy

The meanings of disease have undergone such drastic changes with the introduction of modern Western medicine into China during the last two hundred years that new discourses have been invented to theorize illness, redefine health, and reconstruct classes and genders. As a consequence, medical literature is rewritten with histories of hygiene, studies of psychopathology, and stories of cancer, disabilities and pandemics. This edited volume includes studies of discourses about both bodily and psychiatric illness in modern China, bringing together ground-breaking scholarships that reconfigure the fields of history, literature, film, psychology, anthropology, and gender studies by tracing the pathological path of the "Sick Man of East Asia" through the nineteenth and twentieth centuries into the new millennium.

Readership

Scholars and students interested in modern and contemporary Chinese medical humanities, particularly literature, film, history, psychology, anthropology, and gender studies, as well as medical practitioners concerned with China.

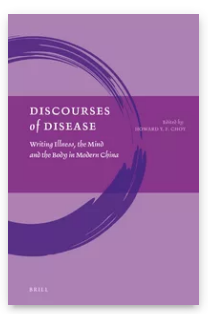

Pages: xiv, 277

pp.

Language:

English

Subjects: China, Asian Studies, Literature \&

Culture, Asian

Studies, Gender

Studies, Asian

Studies, History

of Medicine,

History,

Literature, Arts

\& Science,

Literature and

Cultural Studies

Publisher: Brill

E-Book (PDF)

Released online:

18 May 2016

ISBN: 978-90-

04-31921-9

List price

USD $\$ 158.00$

Hardback

Publication date:

19 May 2016

ISBN: 978-90-

04-31920-2

List price

USD \$158.00 
Howard Y. F. Choy, Ph.D. (2004), University of Colorado at Boulder, is Associate Professor of Chinese Language and Literature at Hong Kong Baptist University. He is the author of Remapping the Past: Fictions of History in Deng's China, 19791997 (Brill, 2008) and numerous scholarly articles.

For more information see brill.com

\author{
Order information: Order online at brill.com \\ +44330 333 o049 | customerservices@brill.com \\ Submission information: brill.com/authors
}

Titles published by Brill | Fink, Brill | mentis or Brill | Schöningh: +49(o)71 5413279216 | brill@brocom.de 